\title{
A Narcissus mosaic viral vector system for protein expression and flavonoid production
}

\author{
Huaibi Zhang ${ }^{1 *}$, Lei Wang ${ }^{1}$, Donald Hunter ${ }^{1}$, Charlotte Voogd ${ }^{2}$, Nigel Joyce ${ }^{3}$ and Kevin Davies ${ }^{1}$
}

\begin{abstract}
Background: With the explosive numbers of sequences generated by next generation sequencing, the demand for high throughput screening to understand gene function has grown. Plant viral vectors have been widely used as tools in down-regulating plant gene expression. However, plant viral vectors can also express proteins in a very efficient manner and, therefore, can also serve as a valuable tool for characterizing proteins and their functions in metabolic pathways in planta.

Results: In this study, we have developed a Gateway ${ }^{\oplus}$-based high throughput viral vector cloning system from Narcissus Mosaic Virus (NMV). Using the reporter genes of GFP and GUS, and the plant genes PAP1 (an R2R3 MYB which activates the anthocyanin pathway) and selenium-binding protein 1 (SeBP), we show that NMV vectors and the model plant Nicotiana benthamiana can be used for efficient protein expression, protein subcellular localization and secondary metabolite production.
\end{abstract}

Conclusions: Our results suggest that not only can the plant viral vector system be employed for protein work but also can potentially be amenable to producing valuable secondary metabolites on a large scale, as the system does not require plant regeneration from seed or calli, which are stages where certain secondary metabolites can interfere with development.

\section{Introduction}

Characterizing the functions of proteins encoded by newly identified DNA sequences is a fundamental aspect of molecular research. Aspects of interest may include the sub-cellular localization of the protein, the activity of the purified protein, or the phenotype resulting from its over-production in planta. The demand for systems to screen for gene function has grown with the increased availability of candidate sequences from next generation sequencing transcriptomics studies and the completion of whole genome sequences. Functional studies of large numbers of genes using stable plant transformation is time-consuming and costly, and thus there is a need for high-throughput screening systems [1]. Preferably, such systems would allow for both high-level production of the encoded protein and observation of the effect on plant phenotype. Systems that enable gene introduction into mature

\footnotetext{
* Correspondence: huaibi.zhang@plantandfood.co.nz

${ }^{1}$ The New Zealand Institute for Plant \& Food Research Limited (PFR), Private Bag 11600 Palmerston North, New Zealand

Full list of author information is available at the end of the article
}

plants have a further advantage of allowing production of proteins or metabolites that may inhibit the usual plant transformation and regeneration processes.

Agrobacterium-mediated transient protein expression systems using conventional binary vectors have been developed to perform various screening tasks [1-3]. Transient expression using plant viral expression vectors can over-express genes not only locally but also systemically before virus-induced gene silencing takes over in the plant tissue. This systemic infection enables production of much larger quantities of plant material in a relative short time frame. Therefore, a viral expression system, combined with the appropriate host plant, could provide an efficient tool for studying protein functions and producing valuable secondary metabolites in planta without having to generate stable transgenic plants. While plant viral vectors have been widely used to down-regulate the expression of endogenous genes [4-9], they have been also developed to over-express heterologous proteins [3,10-16]. However, there can be limitations associated with the different viral systems used.

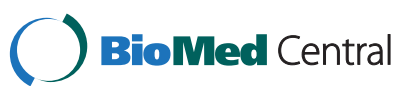

(c) 2013 Zhang et al.; licensee BioMed Central Ltd. This is an Open Access article distributed under the terms of the Creative Commons Attribution License (http://creativecommons.org/licenses/by/2.0), which permits unrestricted use, distribution, and reproduction in any medium, provided the original work is properly cited. 
For example, gene silencing mediated through Potato virus $X$ (PVX) is superimposed upon a visually observed response to the virus itself [17], Tobacco mosaic virus (TMV) can cause pathogenic responses in the host, and it can be difficult to prevent the spread of TMV to nearby non-target plants.

Narcissus Mosaic Virus (NMV) is a potexvirus with a single-stranded RNA genome. Infection of Nicotiana benthamiana plants with NMV (GenBank AY225449) does not cause clearly visible symptoms in the vegetative organs. Plant growth and development in daffodils (Narcissus pseudonarcissus) were apparently normal post NMV infection [18]. N. benthamiana has become one of the standard models for plant biology, including high-throughput over-expression studies [19-22]. The development of a NMV-based expression system for this species would therefore provide an excellent research and biotechnology tool. It may be particularly useful for studies on the anthocyanin biosynthetic pathway, as the $N$. benthamiana varieties used in most laboratories lack anthocyanin production. The anthocyanin biosynthetic pathway, as part of the larger flavonoid pathway, is an important model for a wide range of plant studies, because of both its advantages as a visible reporter system and its key roles in diverse plant functions [23-25]. It is involved in processes such as pollination, fruit dispersal, pathogen resistance and environmental stress tolerance, has been a key model for elucidating transcriptional regulation in plants, and there is growing evidence for the beneficial effects on human health of dietary flavonoids [24,26-28]. In the study presented here, the potential of NMV and $N$. benthamiana as a protein expression system and for secondary metabolite production are explored using both characterized reporter genes (GFP and GUS) and the flavonoid pathway as models. Taking advantage of the many previous studies on transcriptional regulation of flavonoid biosynthesis, a well-characterized R2R3 MYB transcription factor AtMYB75 (PAP1) that promotes anthocyanin biosynthesis in Arabidopsis was used to induce significant changes in metabolite production in inoculated plants, including visible pigment production.

\section{Experimental procedures \\ Plant materials}

Nicotiana benthamiana plants were grown during the southern hemisphere autumn in containment rooms of a double-skin plastic greenhouse facility in Palmerston North, New Zealand (40²1'00"S; $\left.175^{\circ} 36^{\prime} 36^{\prime \prime} \mathrm{E}\right)$. The temperature was controlled by air conditioners to $22+/-2^{\circ} \mathrm{C}$, and no additional lighting was supplied. Fully opened leaves from plants with approximately 10 fully opened leaves were used for biolistic bombardments of viral vectors onto detached leaves and viral inoculation on attached leaves.

\section{Viral vector construction}

A DNA sequence encoding a full length genomic RNA of Narcissus Mosaic Virus New Zealand strain (GenBank: AY225449) was cloned into pCass2 [29] between StuI and BamHI sites to generate pNMV (Figure 1). In pNMV, a duplicated subgenomic promoter for NMV coat protein and AvrII/ApaI cloning sites behind the duplicated subgenomic promoter were created in front of the native coat protein subgenomic sequence. To make a highthroughput cloning vector, the Gateway ${ }^{\odot}$ cloning site (Invitrogen, Auckland, New Zealand) was transferred into pNMV. The attR1-CmR-ccdB-attR2 Gateway ${ }^{\oplus}$ cassette was amplified using the primers $5^{\prime}$-atcctaggACAAG TTTGTACAAAAAAGCAGGCT -3' (forward) and 5'tacctaggGGACCACTTTGTACAAGAAAGCTGGGA -3' (reverse) and a high fidelity DNA polymerase PWO (Roche, Auckland, New Zealand). The AvrII flanked attR1-CmR-ccdB-attR2 cassette was inserted into the AvrII site of pNMV to generate the destination vector pNMV-GW (Figure 1).

To facilitate purification of the proteins expressed using pNMV-GW, a His-tag coding sequence was placed in front of the Gateway ${ }^{\circ}$ cassette. An AvrII-6xHis- attR1CmR-ccdB-attR2-ApaI cassette was assembled using overlapping PCRs, with the first set of primers being $5^{\prime}$ CATCATCACCATCACCATGGACAAGTTTGTACAAA AAAGCAG-3' (forward) and 5'-atcgatgggccACCAC TTTGTACAAGAAAGCTG-3' (reverse), which generated $6 \times$ His-attR1-CmR-ccdB-attR2, and the second set of

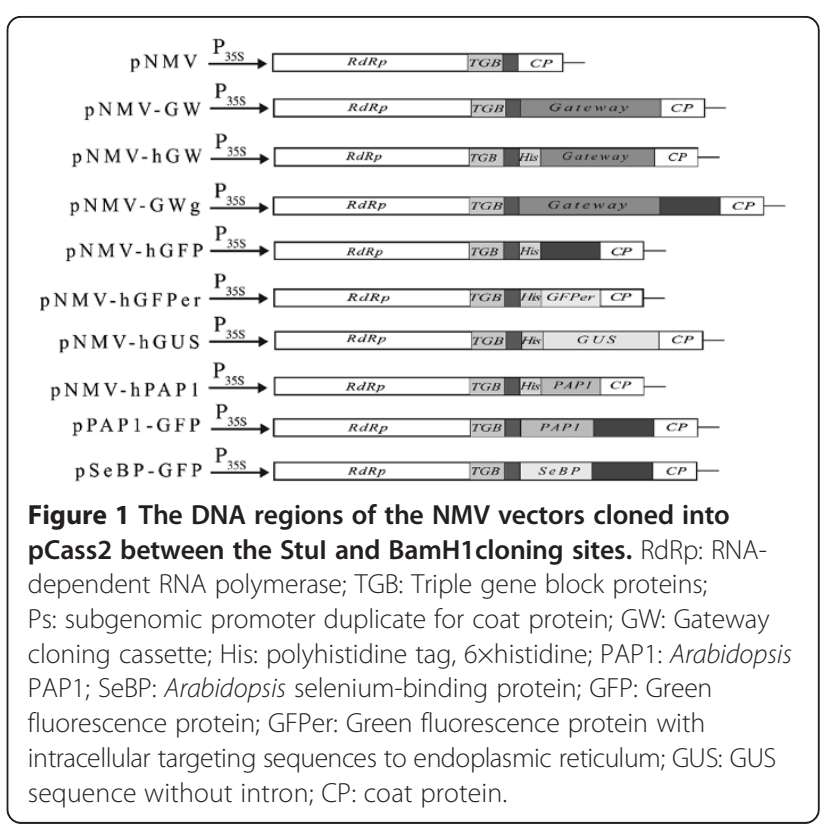


primers being $5^{\prime}$-atcctaggATGCATCATCACCATCACC ATGGA-3' (forward) and 5' -atcgatgggcccACCACTTT GTACAAGAAAGCTG -3' (reverse), which added AvrII and ApaI sites to the $5^{\prime}$ and $3^{\prime}$ ends of the cassette, respectively. The generated AvrII- $6 \times$ His- attR1-CmR-ccdBattR2-ApaI cassette was then inserted between the AvrII and ApaI sites of pNMV to generate the destination vector pNMV-hGW (Figure 1).

To enable GFP tagging of proteins, a vector containing a GFP tag next to the cloning cassette was also constructed. The GFP coding sequence was derived from the $g f p 5$ sequence [30] by cloning it attached to the NMV sequence using the same cloning procedures as used for construction of pNMV, but using the primer pair 5 '-atcctaggACAAGTTTGTACAAAAAAGCAGGC $\mathrm{T}-3^{\prime}$ (forward) and 5'-atcgatgggcccACCACTTTGTA CAAGAAAGCTG -3' (reverse). The AvrII-attR1-CmRccdB-attR2-ApaI Gateway cassette was subsequently inserted in front of the GFP sequence using the AvrII/ ApaI sites such that any sequence inserted into the vector encoded a protein fusion in frame with GFP attached at the $\mathrm{C}$-terminus of the expressed protein of interest. This destination vector was named pNMV-GWg (Figure 1).

The test proteins used were GFP, GFP-ER containing intracellular targeting sequences to endoplasmic reticulum [30], $\beta$-glucuronidase (GUS), Arabidopsis Production of Anthocyanin Pigment 1 (PAP1) and Arabidopsis Selenium-Binding Protein (SeBP). The coding sequences of these proteins were obtained using PCR-amplification with the high fidelity DNA polymerase PWO and the following template DNAs - $p B I N-m-g f p 5-E R$ [30] for GFP and GFP-ER; pRT99-GUS for GUS; PAP1, pGreenII-cPAP (provided by Dr Roger Hellens, Plant \& Food Research, New Zealand); SeBP, pGreenII-cPAP (provided by Dr Roger Hellens, Plant \& Food Research, New Zealand) for PAP1, Arabidopsis cDNA for SeBP (based on the sequence from Agalou et al. (2005). The primers used are listed in Supplementary Data (Additional file 1: Table S1). Through BP and LR reactions as described in the manufacturer's Gateway protocols (Invitrogen), the PCR products flanked with attB1 and attB2 were then cloned into pNMV-hGW to form the expression vectors pNMV-hGFP, pNMV-hGFPer, pNMV-hGUS and pNMV-hPAP1, and PAP1 and SeBP coding sequences into pNMV-GWg to form the subcellular localization vectors PPAP1-GFP and pSeBP-GFP.

\section{Biolistic introduction of viral vectors into $N$. benthamiana leaves}

The pCass2-based viral vector DNAs were propagated in Escherichia coli, extracted, and purified using the Plasmid Plus Maxi Kit following the manufacturer's instructions (QIAGEN, Bio-Strategy Ltd, Auckland, New Zealand). DNA-coated gold particles $(1 \mu \mathrm{m})$ were delivered into the cells of detached fully opened $N$. benthamiana leaves using a helium-driven particle inflow gun [31] and the method of Shang and co-workers [32]. Each detached leaf was bombarded once with $8.0 \mu \mathrm{L}$ of DNA/gold suspension and subsequently placed in a Petri dish with a small amount of water to prevent dehydration, and placed in a culture room in the dark at $25^{\circ} \mathrm{C}$ for 4 to 5 days, and subsequently stored in a $-80^{\circ} \mathrm{C}$ freezer until required.

\section{Inoculation of viral particles into the leaves of intact $\mathrm{N}$. benthamiana plants}

The biolistically transformed detached leaves, being stored in the $-80^{\circ} \mathrm{C}$ freezer, were sealed in small plastic bags with a small amount of water and crushed with a roller to obtain leaf saps. The leaf saps obtained from the detached leaves that had been transformed with different viral vector DNAs were respectively applied by rubbing onto fully-opened carborundum-dusted leaves of the greenhouse plants that had a total of 6-10 leaves. The greenhouse plants were monitored visually and microscopically for the symptoms.

\section{Subcellular localization of proteins with GFP tagging}

GFP fluorescence of the leaves bombarded with pNMVhGFP, pNMV-hGFPer, pPAP1-GFP or pSeBP-GFP was monitored regularly during the incubation period using a fluorescent microscope (Olympus SZX), and final digital images (after 4-5 days) captured using a Leica TCS SP5 confocal microscope (located at Massey University, Palmerston North, New Zealand).

\section{Protein extraction, purification and western analysis}

The GFP protein expression in the leaves of the intact plant was monitored using UV light (Black Ray B100-AP lamp, UV products, Upland, CA 91786, USA) and the leaves that showed systemic infection according to GFP fluorescence were collected for protein extraction.

For the isolation of the proteins containing the His-tag, leaves $(0.5-0.7 \mathrm{~g})$ were ground to a fine powder under liquid nitrogen using a mortar and pestle. Subsequently, the total proteins were extracted by adding $3.0 \mathrm{~mL}$ of the Yeast Protein Extraction Reagent Y-PER $-S$ (Pierce, USA), $30 \mu \mathrm{L}$ of tris(hydroxypropyl)phosphine and $10.0 \mu \mathrm{L}$ of Halt Protease Inhibitor (Pierce, USA). The supernatant (12000 $\mathrm{g}$ for $15 \mathrm{~min}$ ) containing the total soluble proteins was mixed with $1.0 \mathrm{~mL} \mathrm{Ni}$-charged Chelating Sepharose to bind His-tagged proteins. Ni-charged Chelating Sepharose was prepared and the centrifugation approach of Ni-affinity purification was employed according to the manufacturer's protocol (Chelating Sepharose Fast Flow, Amersham Biosciences, Auckland, New Zealand).

For concentrating GUS protein, the total proteins were extracted using the extraction buffer: $50 \mathrm{mM}$ of phosphate buffer ( $\mathrm{pH} 7.0)$ containing $5 \mathrm{mM}$ of DTT, $2 \mathrm{mM}$ 
of EDTA, 0.1\% SDS and 0.1\% Triton X-100. Subsequently, the supernatant was applied to a $3 \mathrm{~mL}$ of open column of diethylaminoethyl cellulose (DEAE) Sepharose (Sigma). The DEAE column was prewashed with the protein extraction buffer prior to sample loading. The loaded column was washed with two column volumes of $0.05 \mathrm{M}$ and then $0.1 \mathrm{M} \mathrm{NaCl}$. One-mL fractions were subsequently collected by eluting the column with $0.2 \mathrm{M} \mathrm{NaCl}$. The concentration of GUS protein in each fraction was monitored through the blue color generated by GUS enzyme activity, by incubating $5.0 \mu \mathrm{L}$ of the fractions in $60.0 \mu \mathrm{L}$ of X-gluc staining buffer [32] for $2 \mathrm{~min}$ at $37^{\circ} \mathrm{C}$. Subsequently, the affinity-purified and the DEAEconcentrated protein fractions were all subjected to PAGE and Western blot analysis.

Sample separation for Western blot analysis of the protein samples was carried out using precast $4-20 \%$ (w/v) SDS-polyacrylamide (SDS-PAGE) gels and the manufacturer's protocol (iGELs, Gradipore, USA). Protein samples were separated on two identical gels, with Precision Plus Protein All Blue Standards (Bio-Rad, Auckland, New Zealand) as molecular mass markers. After separation, one of the gels was stained with Coomassie Blue and the other gel blotted onto a polyvinyllidene difluoride (PVDF) membrane (Millipore), with transfer assisted using an electro-eluter (model 422, Bio-Rad). The PVDF blots were probed with Anti- $\beta$-Glucuronidase Rabbit IgG fraction (Molecular Probes, Oregon, USA), Anti-GFP rabbit IgG fraction (Molecular Probes, Oregon, USA) or mouse monoclonal His-Tag antibody (Novagen, Madison, WI, USA). Western colorimetric detection was carried out using goat Anti-Rabbit IgG -Alkaline Phosphate (AP) (Sigma) or goat anti-mouse AP-conjugated IgG Fab fragments (Boehringer-Mannheim $\mathrm{GmbH}$ ) secondary antibodies. All the antibodies were used according to the respective instructions.

\section{Flavonoid analysis}

The studies on the effect of pNMV-hPAP, pPAP1GFP and pNMV-GFP on flavonoid production in $N$. benthamiana were carried out by inoculating fully opened leaves of plants.

Thin-layer chromatography (TLC) was carried out to confirm the presence of anthocyanins in leaves showing colored foci. Leaves were crushed in water as described for protein extraction, and the extract hydrolyzed with $3 \mathrm{~N} \mathrm{HCl}$ for $45 \mathrm{~min}$ to remove any sugar residues from the anthocyanins (yielding anthocyanin aglycones). The aglycones were enriched in amyl alcohol, spotted onto cellulose TLC plates (CE-400, POLYGRAM ${ }^{\circ}$ polyester sheets, MACHEREY-NAGEL, Germany), and separated on TLC plates using formic acid/concentrated $\mathrm{HC} /$ water solvent (5:2:3, v:v:v).
Flavonoids present in the leaf extracts were analysed by LC-Mass Spectroscopy (LCMS), fitted with an LCMS ion-trap (LTQ ion-trap, Thermo Finnigan, San Jose, California) and electro-spray ionization (ESI) in the negative and positive ion modes. Single MS, MS2 and MS3 data were collected based on parent masses from $280-2000 \mathrm{~m} / \mathrm{z}$ after elution via a PDA detector scanning 220-600 nm (UV-visible). Aliquots of $5 \mu \mathrm{l}$ of sample were separated on a Synergi-Hydro RP, 4 _m, $250 \times 2.1 \mathrm{~mm}$ column with $4 \times 2 \mathrm{~mm}$ guard cartridge (Phenomenex Ltd) at a temperature of $25^{\circ} \mathrm{C}$ with a mobile phase flow rate of $300 \mu \mathrm{L} / \mathrm{min}$. The mobile phase consisted of water (A) and acetonitrile (B) both containing 1\% formic acid (FA) with gradient elution from $98 \%$ A to $50 \%$ B over 45 minutes for general qualitative screening. The column was then washed to a concentration of $80 \%$ (B) for 5 minutes and then reequilibrated with $98 \%$ (A).

\section{Northern RNA analysis}

Total RNA was extracted from the leaves using Trizol reagent according to the manufacturer's instruction (Invitrogen). Twenty $\mu \mathrm{g}$ of total RNAs were resolved in a $1.2 \%$ agarose gel containing $0.66 \mathrm{M}$ of formamide. After electrophoresis, RNAs were blotted onto nylon membranes (Hybond $\mathrm{N}^{+}$membrane, GE Healthcare) and cross-linked to the membrane by UV-C at $70000 \mu \mathrm{J} \mathrm{cm}^{-2}$ (Hoefer, San Francisco, CA) for 1 min. Radiolabeled $\left(\left[\alpha-{ }^{32} \mathrm{P}\right] \mathrm{dCTP}\right)$ was used to prepare $\left[{ }^{32} \mathrm{P}\right]$-radiolabeled DNA probes using the HighPrime (Roche Applied Science) labelling kit, with GFP and PAP1 DNAs being used as templates. Hybridization against $\left[{ }^{32} \mathrm{P}\right]$-radiolabeled DNA probes was carried out as described in Deroles et al. (1998), except with a final wash stringency of $65^{\circ} \mathrm{C}$ and $0.5 \times$ SSC to remove nonspecific bindings of the radioactive signals.

\section{Results}

\section{Construction of NMV expression vectors}

To enable NMV infection in plants without having to use in vitro reverse transcription, a construct was prepared that placed a DNA sequence for the viral RNA genome in a plant expression cassette, driven by the $35 \mathrm{SCaMV}$ promoter, with a duplicate subgenomic promoter for the coat protein of NMV placed in front of a cloning site immediately upstream of the native sequence for the coat protein (pNMV, Figure 1). To allow for high throughput cloning, a version of pNMV was prepared that utilizes the Gateway site-specific recombination system between the duplicate subgenomic promoter and the native subgenomic promoter for the coat protein for rapid cloning, specifically the (pNMV-GW, Figure 1). The pNMV-GW vector was constructed so that no start codon occurred in front of the Gateway ${ }^{\circ}$ 
Figure 2 Subcellular localization of GFP and GFP-tagged proteins expressed in the leaves of $\boldsymbol{N}$. benthamiana. A: GFP without basic chitinase signal peptide at the $\mathrm{N}$-terminus and the ER-retention peptide HDEL at the C-terminus; B: GFP containing the basic chitinase signal peptide at the $\mathrm{N}$-terminus and the ER-retention peptide HDEL at the C-terminus; C: PAP1-GFP fusion protein; D: SeBP-GFP fusion protein.

cassette, enabling the endogenous start codon of any coding sequence (CDS) to be used.

The pNMV-GW vector was further modified to facilitate intracellular localization of proteins and rapid protein purification. For localization studies pNMV-GW was modified to result in formation of the expressed proteins with Green Fluorescent Protein (GFP) as a C-terminal fusion of a expressed protein (pNMV-GWg, Figure 1). The GFP CDS was placed downstream of the Gateway ${ }^{\circ}$ attB2 recombination sequence for easier in-frame fusion of the target CDS and GFP. Target sequences for expression are PCR amplified, spanning from the CDS ATG to the codon before the stop codon, using primers flanked with the Gateway attB1 and attB2 sequences.

To allow purification of expressed proteins using Nibased affinity purification, a leader sequence containing a six-histidine peptide tag and an ATG start codon was placed in frame with attB1, creating pNMV-hGW (Figure 1), and providing for Gateway ${ }^{\circ}$ cloning into the attB1 and attB2 vector sequences.

\section{Subcellular localization of proteins expressed with NMV vectors}

Two different versions of GFP were expressed using pNMV-hGW to examine the affect on protein sub-cellular localization of the inclusion of either the His-tag or two ER-localization signals used to aid protein accumulation. The basic chitinase signal peptide and the ER-retention signals were used, the Arabidopsis basic chitinase signal on the N-terminus and the HDEL motif [30] on the C-terminus, giving pNMV-hGFPer (Figure 1). The basic chitinase signal was placed immediately following the His tag.

The two vectors were introduced into $N$. benthamiana leaves using biolistics and the sub-cellular pattern of accumulation determined using confocal microscopy. The His-tag at the N-terminus did not alter the typical intracellular distribution of GFP signal to the cytoplasm (Figure 2A). However, the ER-localization signals caused GFP signal to accumulate in a pattern that probably represents the ER lumen (Figure 2B). The presence of the His-tag apparently did not affect the action of the ER-localization signals.

Two Arabidopsis genes, PAP1 (AtMYB75, $28 \mathrm{kDa}$ ) and selenium-binding protein 1 ( $\mathrm{SeBP} 1,55 \mathrm{kDa})$, were also 
used in the localization study. PAP1 is a relatively small R2R3 MYB transcription factor, the over-expression of which has been demonstrated to induce anthocyanin biosynthesis in Arabidopsis and tobacco [33]. SeBP1 is a much larger protein that has been extensively characterized for its role in heavy metal tolerance [34]. The GFPtagging vector pNMV-GWg was used to generate pPAP1-GFP and pSeBP-GFP (Figure 1). After biolistic transformation of the detached $N$. benthamiana leaves with pPAP1-GFP and pSeBP-GFP DNAs, localization of the GFP-tagged PAP1 and SeBP1 proteins was examined using confocal microscopy. Nuclear localized GFP signal was observed for pPAP1-GFP (Figure 2C) and a cytoplasmic GFP signal for pSeBP-GFP (Figure 2D), matching the known localization of the native proteins.

\section{Protein expression and purification using the NMV vectors}

To examine the flexibility of the NMV system, production of not only the relatively small reporter GFP (approximately $27 \mathrm{KDa}$ ), but also that of the relatively large reporter protein GUS (approximately $68 \mathrm{KDa}$ ) were examined, using the vector pNMV-hGUS. GUS activity, as assayed by GUS staining, was evident five days after biolistic bombardment of pNMV-hGUS into $N$. benthamiana leaves (Additional file 2: Figure S1). GUS protein accumulation was confirmed in leaves of intact plants in the greenhouse that had been inoculated with the extracts of the pNMV-hGUS-bombarded leaves (Additional file 2: Figure S1), using a activity assay, coomassie Blue protein staining and the Western blot analysis (Figure 3). Total protein extracted from the inoculated greenhouse plants was passed through an open DEAE column and the GUS activity assayed in the eluted fractions. Strong blue color was observed within 2 min of incubation only in the fractions that contained enriched GUS protein (Figure 3A, insert). Western analysis using anti-GUS (Figure 3A) and anti-His antibody (Figure 3B) detected GUS protein in those DEAE column fractions that had shown high GUS activity.

The pNMV-hGUS plants were also tested for their applicability with the rapid $\mathrm{Ni}$-affinity purification system. Commassie Blue staining (Figure 3C) and Western analysis (Figure 3D) showed that the $\mathrm{Ni}$-affinity protocol was highly effective for purification of the GUS protein expressed from pNMV-hGUS-inoculated greenhouse plants. The GUS protein purified with Ni-affinity was equivalent to $10 \mathrm{mg}$ per $\mathrm{kg}$ fresh weight of the leaf shown in Additional file 2: Figure S1.

The use of GFP as one of the reporters also allowed for easy examination of the timeframe of NMV infection and spread. Local infection foci were apparent about five days post inoculation (dpi) and systemic infection was well established by about $10 \mathrm{dpi}$. The results were similar

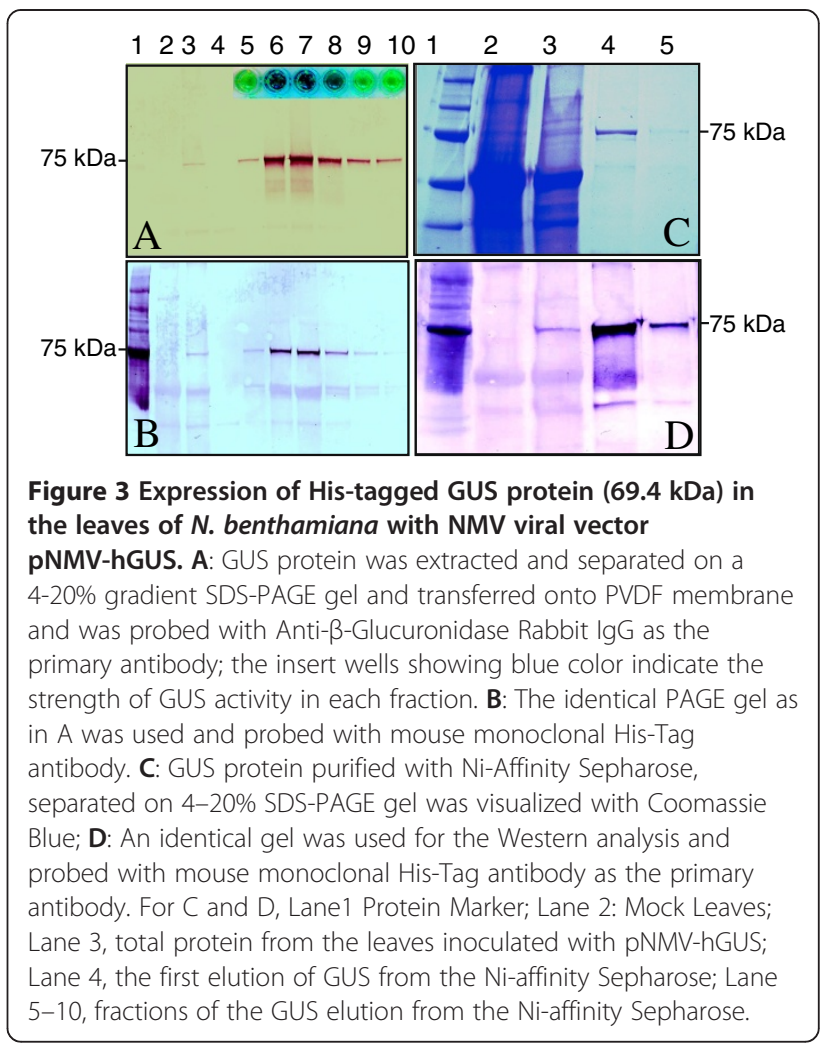

whether pNMV-hGFP or pNMV-hGFPer was used. However, long-term accumulation of GFP appeared stronger for pNMV-hGFPer than pNMV-hGFP (Figures 4A and B). Western analysis of total protein extracts showed that anti-GFP antibody detected GFP accumulation from both pNMV-hGFPer and pNMV-hGFP (Figure 4C), but antiHis antibody detected GFP accumulation only from pNMV-hGFP (Figures 4B and C). When the total proteins were purified using the Ni-affinity method, strong signals were detected on the Western analysis with both the antiGFP and anti-His-antibodies with samples from plants inoculated with pNMV-hGFP, but not with those from pNMV-hGFPer plants (Figures 4B and C).

\section{Expression of PAP1 in $N$. benthamiana using pNMV vector}

The GFP and GUS protein expression experiments demonstrate that NMV is an effective tool for over-expressing proteins in $N$. benthamiana. To examine its utility for proteins of biological interest and application for studying metabolic pathways, an Arabidopsis protein was tested, PAP1 (AtMYB75, $28 \mathrm{kDa}$ ). The PAP1 CDS was cloned into pNMV-hGW to generate pNMV-hPAP1 (Figure 1).

The vectors pNMV-hPAP1 along with the control pNMV-hGFP, were biolistically introduced into detached $N$. benthamiana leaves. After five days in the dark, the leaves that received pNMV-hPAP1 DNA produced darkcolored foci, while no colored foci were visible on pNMV-hGFP leaves (Additional file 3: Figure S2). 


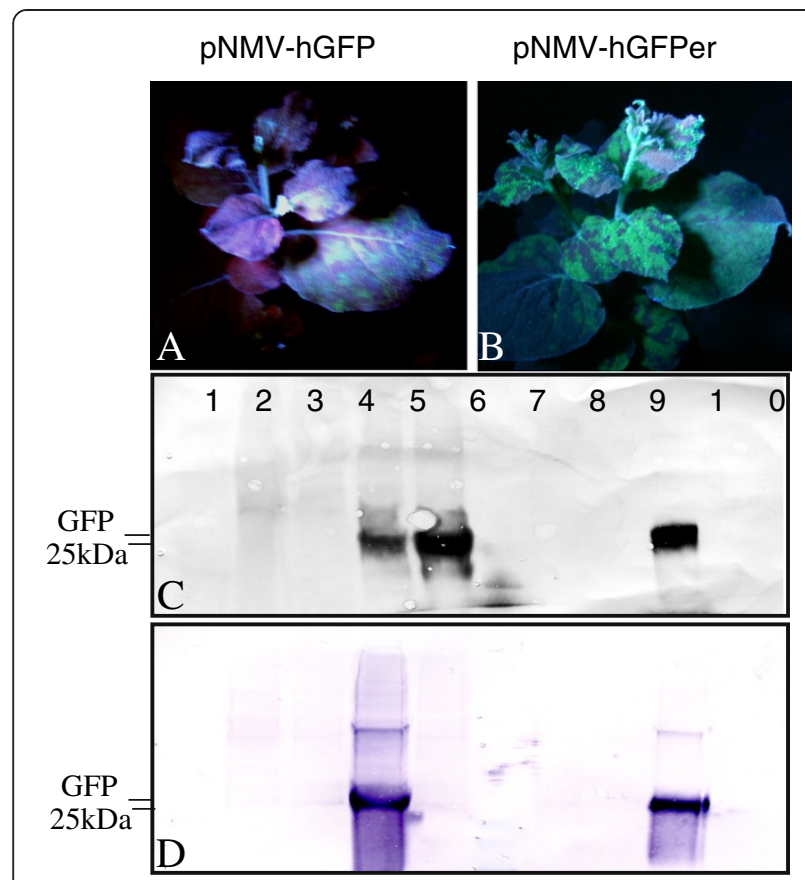

Figure 4 Expression of His-tagged GFP (27 kDa) in the leaves of $N$. benthamiana with NMV viral vector pNMV-GFP and pNMVGFPer. A: Image taken under UV light, showing systemic distribution of GFP without basic chitinase signal peptide at the $\mathrm{N}$-terminus and the ER-retention peptide HDEL at the C-terminus; B: Image taken under UV light, showing systemic distribution of GFP containing basic chitinase signal peptide at the N-terminus and the ERretention peptide HDEL at the $\mathrm{C}$-terminus; $\mathbf{C}$ : total proteins were extracted from the leaves inoculated with pNMV-GFP and pNMVGFPer respectively and separated on a 4-20\% SDS-PAGE gel, transferred onto PVDF membrane and probed with Anti-GFP rabbit IgG. Lane 1: Protein Marker; Lane 2: Mock control; Lane 3: leaves inoculated with pNMV-PAP1, Lane 4: inoculated with pNMV-hGFP Lane 5: the leaves inoculated with pNMV-hGFPer; Lane 6-10 were the same samples as in Lane 1-5 but having gone through $\mathrm{Ni}$ Sepharose affinity purification. D: Identical Western blot as in C but probed with mouse monoclonal His-Tag antibody as the primary antibody.

Extracts of leaves of these plants were then inoculated onto fully opened leaves of $N$. benthamiana greenhouse plants, while control plants were mock-inoculated. Large numbers of dark-red foci appeared in the leaves of plants treated with pNMV-hPAP1 inoculate after 7 dpi (Figure 5A). The pigmentation was uneven across the colored foci (Figure 5B), as might be expected from the nature of the viral infection process. The pNMVhGFP inoculate did not generate visible foci, although GFP foci were apparent under the UV light (Figure 5C). The supernatants of homogenized pNMV-hPAP1 and pNMV-hGFP expressing leaves were markedly different in color (Figure 5D), with the orange color indicating the production of anthocyanins. Accumulation of delphinidinbased anthocyanins in the pNMV-hPAP1 plants was confirmed by TLC (Figure 5E). The pPAP1-GFP vector

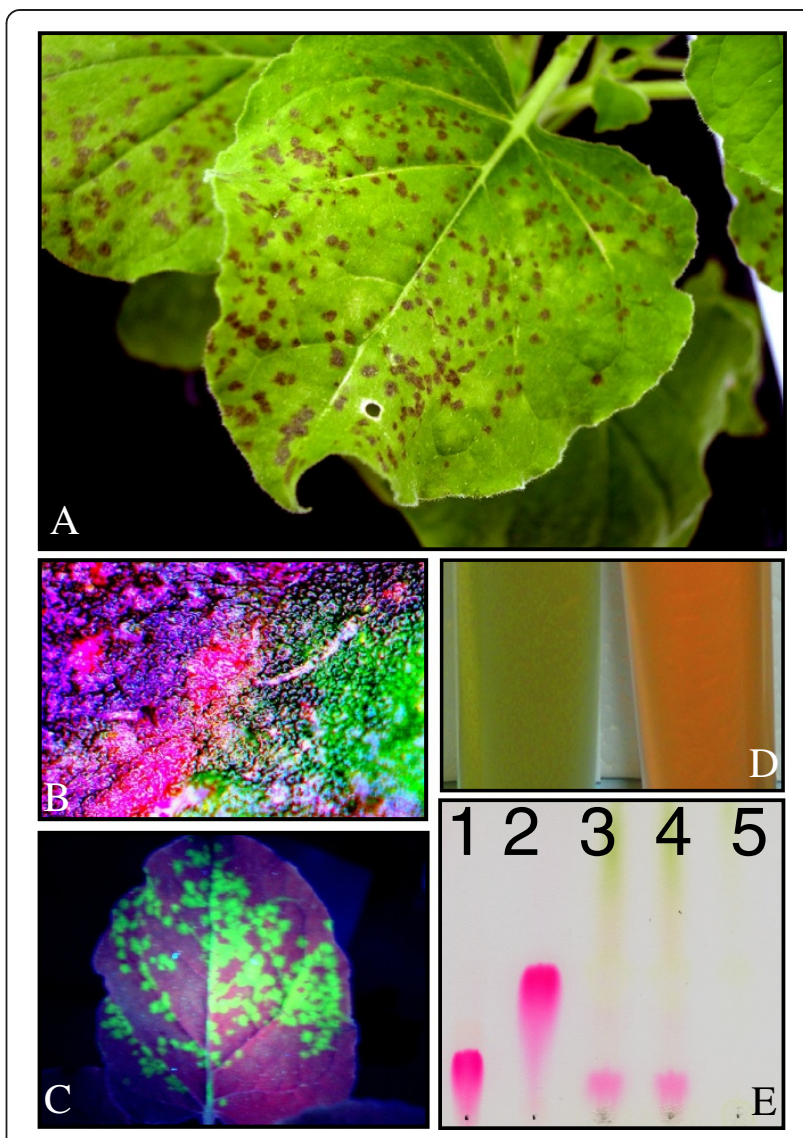

Figure 5 Expression of PAP1 in the leaves of $N$. benthamiana with pNMV-hPAP1 viral vector. A: Anthocyanic foci at $7 \mathrm{dpi}$; B: Uneven-colored anthocyanic pigmentation across foci; C: GFP foci; D: Showing color difference of the extract supernatants from leaves inoculated with pNMV-hGFP (L) and pNMV-hPAP1 (R). E: TLC

displaying anthocyanidin extracted from the leaves inoculated with pNMV-hPAP1 vector, from L to R: delphinidin, cyanindin, sample1, sample 2 and pNMV-hGFP control.

also generated colored foci, but with a much reduced efficiency than pNMV-hPAP1 (data not shown).

\section{Changes in flavonoid production resulting from PAP1and PAP1-GFP expression in $N$. benthamiana leaves}

To investigate the effect of pNMV-expressed PAP1 and PAP1-GFP proteins on the flavonoid pathways in the $N$. benthamiana leaves, flavonoid metabolic profiles of leaves inoculated with extracts for PAP1, PAP1-GFP, GFP and the mock control were analyzed using LC-MS. The LC results showed no detectable anthocyanins in the leaves of the mock control or plants expressing GFP only (Figures $6 \mathrm{~A}$ and $\mathrm{B}$ ). However, the leaves expressing PAP1-GFP or PAP1 produced an identical anthocyanin peak with an absorption at $525 \mathrm{~nm}$ (Figures 6C-F), in agreement with the visual observation and TLC results (Figure 5E). This anthocyanin peak generated a molecular ion mass at $\mathrm{m} / \mathrm{z} 611$, suggesting that the anthocyanin 

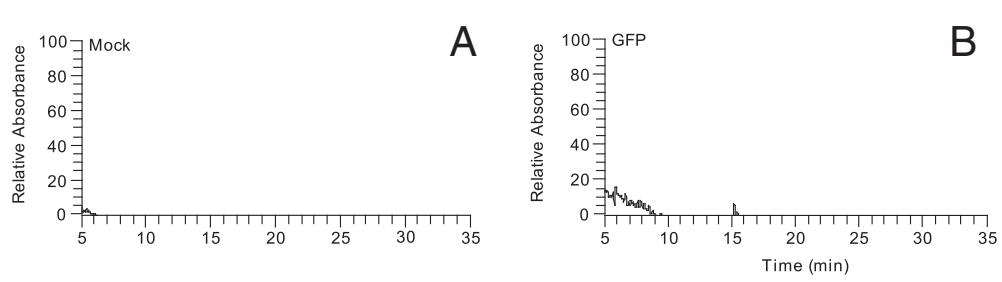

B
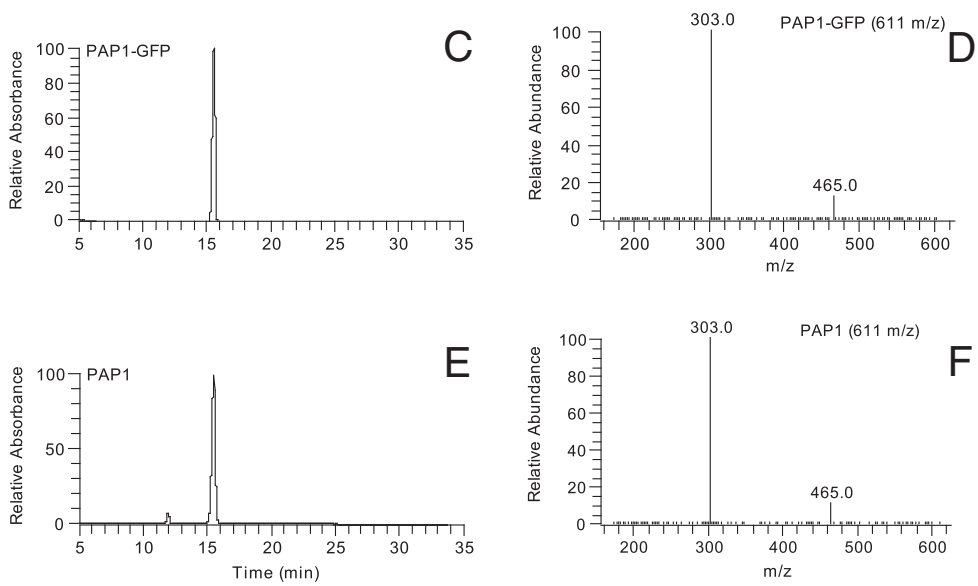

Figure 6 LC/MS Anthocyanin analyses in the leaves of $\boldsymbol{N}$. benthamiana plants with different inoculations. LC peaks were revealed at 520 $\mathrm{nm}$ absorption wavelength. A: LC, mock-inoculated leaves; B: LC, the leaves inoculated with viruses derived from pNMV-GFP; C: LC, the leaves inoculated with viruses derived from PPAP1-GFP; $\mathbf{D}$ : MS fragmentation of the molecular ion of delphinidin-3-O-rutinoside $(\mathrm{m} / \mathrm{z} 611)$ in the peak detected at $520 \mathrm{~nm}$ in $\mathbf{C} ; \mathbf{E}$ : LC, the leaves inoculated with viruses derived from pNMV-PAP1; F: MS fragmentation of the molecular ion (611 m/z) in the peak detected at $520 \mathrm{~nm}$ in E to reveal the component ions delphinidin-3-O-glucoside $(\mathrm{m} / \mathrm{z} 465)$ and delphinidin $(\mathrm{m} / \mathrm{z} 303)$.

was delphinidin-3-O-rutinoside (a glucose at the C-3, with a rhamnose attached to the glucose). This was verified by further fragmentation of m/z 611 into m/z 303 (delphinidin), m/z 465 (delphinidin-3-O-glucoside) and the $\mathrm{m} / \mathrm{z} 144$ (rhamnose) (Figures 6D, F).

Although $N$. benthamiana leaves do not produce anthocyanins naturally, they are capable of producing another group of flavonoids, the colorless flavonols. LC results showed that three flavonoid peaks were detected in the mock control and the leaves expressing GFP, and the patterns of the peaks appeared almost identical (Figures $7 \mathrm{~A}$ and $\mathrm{B}$ ), indicating that viral activity alone did not alter the flavonol profile. However, leaves expressing PAP1 or PAP1-GFP produced not only the three peaks present in control plants (F1, F2 and F3) but also a new peak, F4 (Figures 7C and D). Peak F4 was much higher in the leaves expressing PAP1 than in those expressing PAP1-GFP. MS analysis revealed that in all the samples the peaks for F1, F2 and F3 produced molecular ion masses at $\mathrm{m} / \mathrm{z} 595,465$ and 611, respectively (Additional file 4: Figure S3). Further fragmentation indicated that all three compounds were flavonols, with $\mathrm{m} / \mathrm{z} 595$ (F1) being kaempferol-3-O-rutinoside (m/z 287 and $\mathrm{m} / \mathrm{z} 449$ ), $\mathrm{m} / \mathrm{z} 465$ (F2) being quercetin-3-O-glucoside $(\mathrm{m} / \mathrm{z}$ 303) and $\mathrm{m} / \mathrm{z} 611$ (F3) being quercetin-3-Orutinoside $(\mathrm{m} / \mathrm{z} 303$ and $\mathrm{m} / \mathrm{z}$ 465). Peak $\mathrm{F} 4$ had a molecular ion mass at $\mathrm{m} / \mathrm{z} 627$, and no trace of ion mass at $\mathrm{m} / \mathrm{z} 627$ were detected in mock or pNMVhGFP-inoculated control plants. Mass fragmentation indicated that $\mathrm{m} / \mathrm{z} 627$ represented the flavonol myricetin-3-O-rutinoside (m/z 319 and $\mathrm{m} / \mathrm{z}$ 481). Myricetin has three hydroxyl groups on the B-ring of the molecular $\left(\mathrm{C}-3^{\prime}, 4^{\prime}\right.$ and $\left.5^{\prime}\right)$, while quercetin and kaempferol have only two or one B-ring hydroxyl, respectively.

\section{Efficiency of NMV replication in N. benthamiana}

Northern RNA analysis with GFP and PAP1 cDNA probes was used to assess the genome replication of the NMV vectors in N. benthamiana. Both probes revealed the genomic and triple gene block subgenomic RNAs but not the region corresponding to the $\mathrm{CP}$ sequence (Figure 8). With GFP probe, the RNA genome of viruses from pNMV-hGFP accumulated to high amounts in the leaves (Figure 8A). However, while the RNA genome of viruses derived from pPAP1-GFP was easily detected, the concentrations were much lower than those from pNMV-hGFP (Figure 8A). The mock control and samples from pNMV-hPAP1 inoculation did not produce any signal with the GFP probe, as expected. When the PAP1 probe was used, both genomes of transgenic viruses from pNMV-hPAP1 and pPAP1-GFP were 


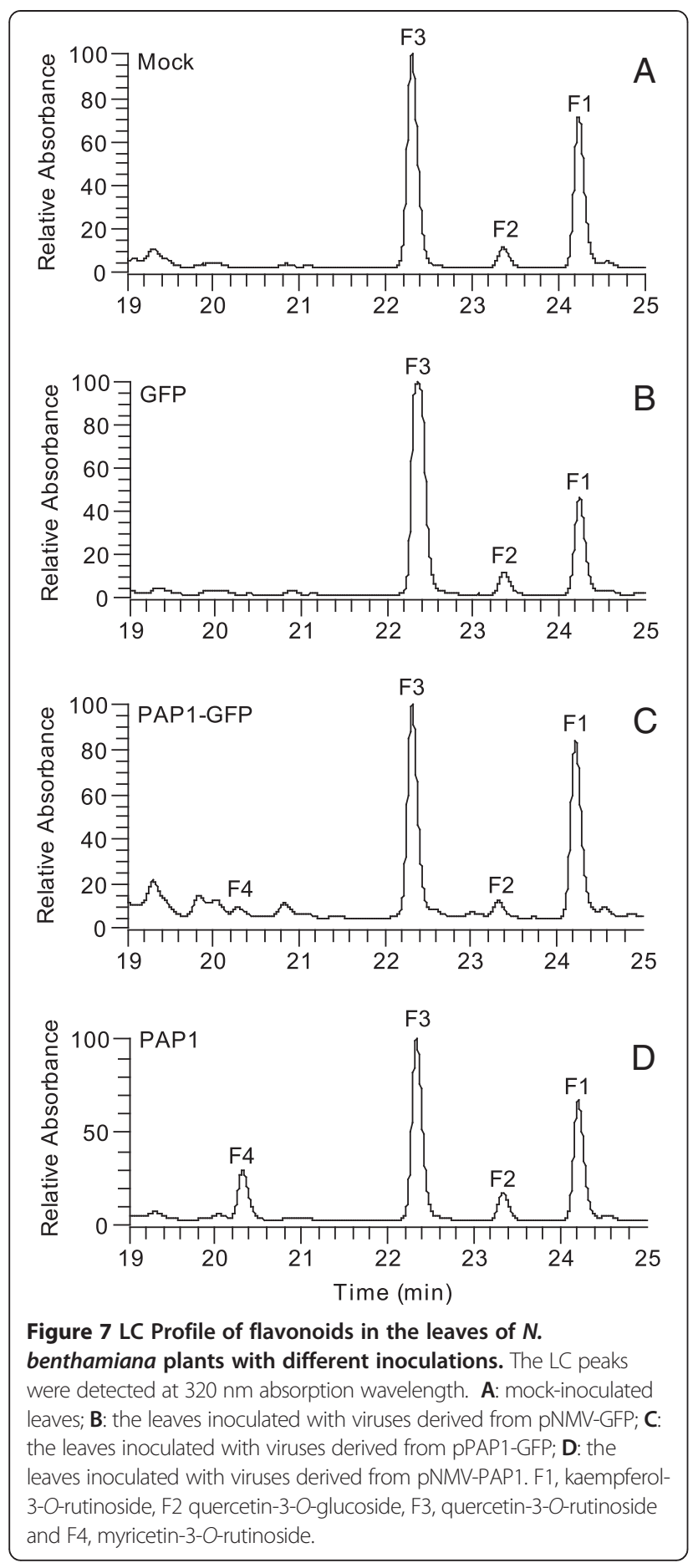

detected in the $N$. benthamiana leaves, although again at lower concentrations than when pPAP1-GFP vector was used (Figure 8B). Based on the size detected, fulllength viral genomic RNAs were accumulated (Figure 8).

\section{Discussion}

A range of virus-based plant transient expression systems has been developed for protein expression [13,16,35-39].

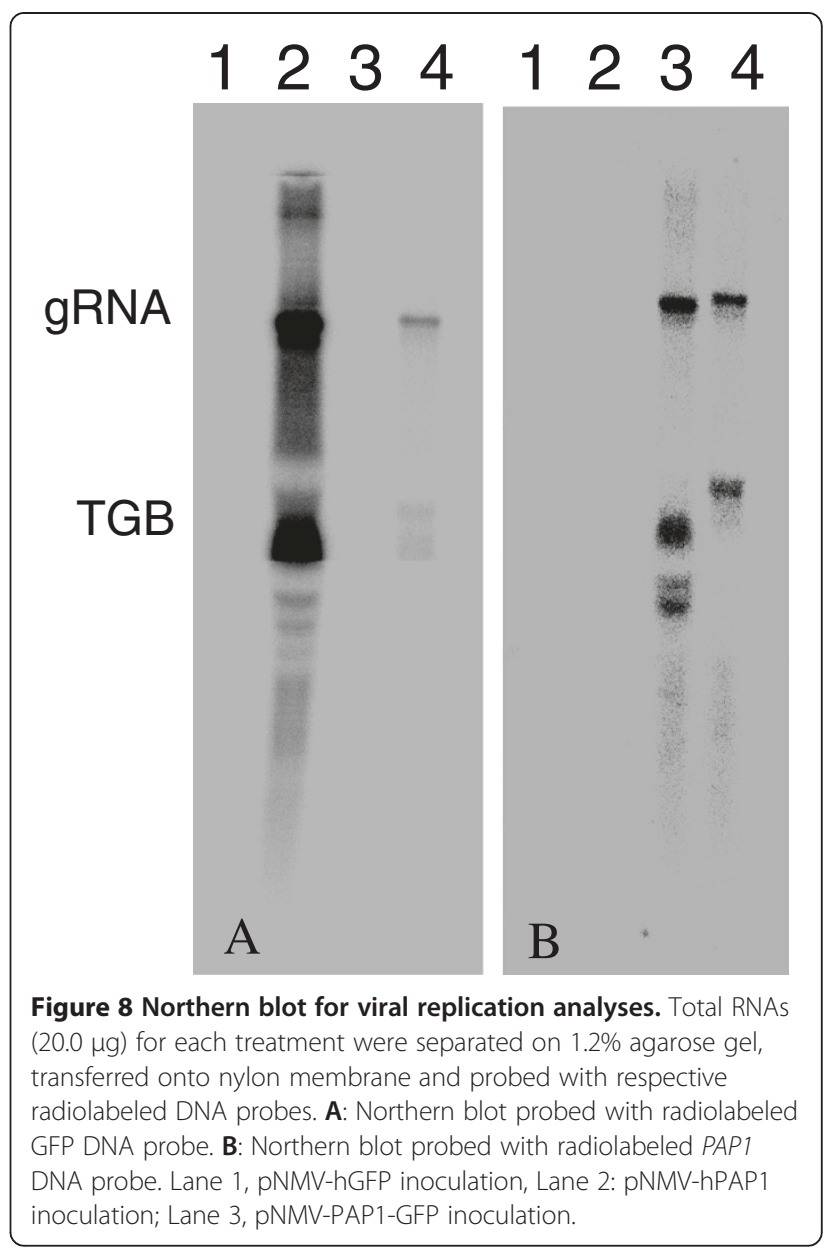

Plant viral vector systems have several advantages over other systems, such as rapid and systemic infections, and also avoid the risks associated with the use of animal pathogens for production of recombinant proteins or vaccines [11,40-43]. However, there are also drawback of viral-based systems, including pathogenic host responses, spread to non-target plants and a lack of viral systems for a wide range of host plants. We report here a new viral expression system based on NMV and N. benthamiana, and incorporating the Gateway cloning system, that addresses some of these drawbacks.

NMV isolated from New Zealand is a mild strain that replicates very efficiently in $N$. benthamiana but does not cause visible pathogenic symptoms. It also has a very limited host range, reducing the risk of the unintentional spread of the virus. $N$. benthamiana is a model species of growing importance $[22,44]$, and has previously been used with viral vectors for studies of secondary metabolism, such as alkaloid biosynthesis [45], the production of flavor enzymes [46], and as a production platform for small pharmaceutical molecules [47]. 
The Gateway ${ }^{\oplus}$ system was incorporated into the base NMV vectors we developed to enable higher throughput cloning of the genes of interest without the need for use of restriction enzymes. Gateway ${ }^{\circ}$ technology is well established as a highly efficient system for high throughput applications [37,48-52]. The effectiveness of the base NMV vectors (pNMV-GW, pNMV-GWg and pNMV-hGW) for Gateway ${ }^{\circ}$ cloning and protein expression was demonstrated for both reporter genes and genes involved in the regulation of endogenous biosynthetic pathways. The base vectors were all shown to drive accumulation of expressed protein after only a few days post-inoculation, using either biolistic DNA delivery or a viral particle inoculation. The inclusion of a His-tag enabls rapid protein purification. A simple Ni-affinity purification step led to the highly purified GUS protein, as evidenced by commassie blue staining and the Western blot analysis. The purified level of GUS protein by Ni-affinity (10 mg per kg FW) suggests that the NMV viral system has the potential to produce high level proteins, given the material used for protein measurement only had local infection foci (Additional file 1: Figure S1) on the biolistically transformed leaf. The local foci account for a very small proportion of the leaf tissue (systemic infection would produce much higher proportion of infected materials). As an alternative to the His-tag, the DEAE column tests and Western blotting analyses with GUS suggested that NMV-expressed proteins can be easily enriched by column chromatography while retaining protein functionality.

The effect of the His-tag on the GFP for determining sub-cellular localization of proteins was examined in detail using GFP with or without ER retaining signals. Clearly, addition of the His-tag to both versions of the GFP did not alter the behavior of intracellular trafficking of the GFP. The results indicates that the His-tag will be unlikely to affect the function of a expressed protein, as confirmed in this study, where the His-tagged PAP1 was highly efficient in turning on the limiting step(s) of anthocyanin biosynthesis pathway in $N$. benthamiana, a species that is normally anthocyanin-less. A further advantage of the NMV vectors for localization studies is that infection foci are easily visible as GFP-positive foci, because of multi-celled infection clusters forming, but within the foci, cells showing a range of expression levels of the GFP-tagged protein are apparent, allowing studies as to whether the protein concentration is altering localization.

Higher protein concentrations were achievable when an ER retention signal was added to the vectors, although this by nature precludes studies on normal subcellular localization. The higher GFP signals seen when using the ER signal motifs support previous studies on ER retention as a means to increase protein overexpression levels [30]. ER retaining signals can also be used to alter the post translational modification of an expressed protein [53]. The Western analyses in this study has suggested that the His-tag along with the N-terminal ER signal were removed in the plant cell after the protein was transported into ER, according to the Western analyses for the total protein. This was confirmed with Niaffinity purification of the GFPs, as the GFP tagged with both His and ER signal peptide was unable to be retained by the Ni-affinity material. However, the very small Histag could be placed behind the N-terminal ER signal or C-terminus of the fused proteins to prevent its being cleaved.

Transgenic viruses often show instability of the inserted protein sequence [35], particularly with large sequence inserts. However, the NMV system was effective in expressing both relatively small (GFP) and large (GUS) proteins within the timeframe of the experiments carried out in this report. The results in this study also indicated that gene inserts in the NMV viral vectors are stable after the passage from the biolistically transformed material to intact plants, as evidenced by the efficient expression of the insert genes in the whole plant. The capability to express GUS protein $(68 \mathrm{KDa})$ in a NMV system suggests that large transcription factors, such as bHLHs that are involved in the regulation of flavonoid biosynthesis pathways, could also be expressed with this system. The pattern of GFP spread (locally and systemically) found in this study suggests that NMV shows behaviors similar to those characterized for other Potex viruses $[16,54,55]$. This long period of stable protein expression, in combination with the ease of systemic infection, suggests that the NMV system may provide an efficient platform for over-expression, purification and sub-cellular localization of proteins of interest.

The results show that NMV vectors can be used in the expression and purification of proteins in planta. The applicability of the NMV system for studying the function of expressed proteins in endogenous metabolic pathways was demonstrated by using the anthocyanin pathwayrelated R2R3 MYB PAP1 (AtMYB75). N. benthamiana has been demonstrated to be an effective model plant for identifying proteins associated with secondary metabolism $[45,56,57]$. However, for unknown reasons, the laboratory lines of $N$. benthamiana used do not show production of anthocyanin pigments. PAP1 is a strong activator of anthocyanin biosynthesis in both Arabidopsis and heterologous hosts [33], and it was decided to examine whether NMV-based over-expression of PAP1 could induce anthocyanin production in $N$. benthamiana leaves.

Dark-red anthocyanic-like foci were clearly visible by 7 dpi of the His-tagged PAP1 virion on the leaves of intact plants, suggesting that the entire anthocyanin biosynthetic pathway is present in $N$. benthamiana, and that lack of activity of a regulatory gene expression is 
the cause of the usual acyanic phenotype. The inclusion of the His-tag or a GFP fusion did not prevent PAP1 activity, suggesting they did not interfere with the formation of the necessary MYB-bHLH-WD40 anthocyanin regulatory complex in plants [28,58-60]. This is despite the fact that the GFP protein of $27 \mathrm{kDa}$ is of a similar size to the MYB protein (approximately $28 \mathrm{kDa}$ ). Some viruses can be responsible for anthocyanin accumulation in other plant species [61]; however, the control of NMV expressing GFP and mock-inoculation controls did not show any anthocyanin induction.

LC/MS was used to confirm that anthocyanin production was indeed induced by PAP1 over-expression, with delphinidin-3-O-rutinoside found to accumulate. It also allowed for the examination of the effect of PAP1 on nonanthocyanin flavonoids. Although control $N$. benthamiana plants lacked anthocyanins, they had a basal production of the flavonols kaempferol-3-O-rutinoside and quercetin3-O-rutinoside, which are from branches off the flavonoid pathway prior to anthocyanins. Interestingly, in addition to inducing anthocyanin production, PAP1 and PAP1-GFP over-expression also caused the accumulation of a flavonol not detected in the control plants, myricetin3-O-rutinoside. As both delphinidin and myricetin have 3' 4' 5 '-hydroxylation of the flavonoid B-ring, this suggests that PAP1 is activating the gene(s) for the flavonoid 3' 5 'hydroxylase $\left(\mathrm{F}^{\prime}{ }^{\prime} 5^{\prime} \mathrm{H}\right)$. Interestingly, one of the reasons behind high anthocyanin production in tomato only being possible with specific anthocyanin-related transcription factor combinations is thought to be whether they can activate the $\mathrm{F}^{\prime} 5^{\prime} \mathrm{H}$, as specificity of substrate use is known for some of the flavonoid biosynthetic enzymes in the Solanaceae [62].

Based on RNA analysis, there was variation in the replication efficiency of the vectors. The GFP-containing NMV replicated more efficiently than either the PAP1 vector, which is a DNA insert of similar length to GFP, or the PAP1-GFP vector. The RNA measurements match visual observations that GFP foci appear earlier on inoculated leaves when using the GFP vector. One possibility is that the slow movement or replication of the PAP1 containing NMV was caused by the very high concentrations of the flavonoids accumulated in the cells, as flavonoids have been suggested to have anti-viral roles [63].

In conclusion, the results presented here demonstrate that the combination of the NMV Gateway vectors and $N$. benthamiana provides an efficient platform for protein expression, purification, intracellular localization and also plant secondary metabolite production, as a research tool and also potentially as a biotechnology tool. A recent published work [64] has reinforced the value of plant viral vectors in not only the production of macromolecules but also small phytochemicals such as plant pigments.

\section{Additional files}

Additional file 1: Table S1. Primers used in constructing the attB1 and attB2 flanked PCR products for pNMV-hGUS, pNMV-hGFP, pNMV-hGFPer, pNMV-PAP1-GFP, pNMV-SeBP-GFP pNMV-hPAP1. High fidelity PWO DNA polymerase (Roche) was used.

Additional file 2: Figure S1. Detached Nicotiana benthamiana leaves incubated for 5 days in the dark after biolistic introduction of NMV-hGUS DNAs. The GUS staining was according to the method of [32].

Additional file 3: Figure S2. Detached Nicotiana benthamiana leaves incubated for 5 days in the dark after biolistic introduction of pNMVhGFP and pNMV-hPAP1 DNAs.

Additional file 4: Figure S3. MS fragmentation of the flavonoids revealed in the Figure 7. F1, kaempferol-3-O-rutinoside ( $\mathrm{m} / \mathrm{z} 595)$, kaempferol-3-O-glucoside ( $m / z$ 449), kaempferol ( $\mathrm{m} / \mathrm{z} 287$ ); F2, quercetin3-O-glucoside ( $\mathrm{m} / \mathrm{z} 465)$, quercetin $(\mathrm{m} / \mathrm{z} 303), \mathrm{F} 3$, quercetin-3-Orutinoside ( $\mathrm{m} / \mathrm{z}$ 611), quercetin-3-O-glucoside $(\mathrm{m} / \mathrm{z} 465)$, quercetin $(\mathrm{m} / \mathrm{z}$ $303)$ and F4, myricetin-3-O-rutinoside ( $\mathrm{m} / \mathrm{z} 627)$, myricetin-3-O-glucoside $(\mathrm{m} / \mathrm{z} 481)$ and myricetin $(\mathrm{m} / \mathrm{z} 319)$.

\section{Authors' contributions}

$\mathrm{HZ}$ designed, carried out the experiments and wrote the manuscript draft LW contributed to the vector cloning and the Northern analysis.

$\mathrm{DH}$ contributed to the vector cloning, result analysis and the writing of the manuscript. CV made the cDNA clone of the Narcissus Mosaic virus. NJ carried out the LC-MS KD contributed to research management, result analysis and the writing of the manuscript. All authors and approved the final manuscript.

\section{Acknowledgements}

David Lewis and Steve Arathon are thanked for their help with anthocyanin TLC, and Tony Corbett for photography and the figures. The authours are grateful to Drs Andrew Allan and Dave Brummell for valuable comments on the manuscript. The authours would like to thank lan King and Julie Ryan for growing the experimental plants. The work was funded by the New Zealand Ministry for Science and Innovation, contract number C02X0805.

\section{Author details}

${ }^{1}$ The New Zealand Institute for Plant \& Food Research Limited (PFR), Private Bag 11600 Palmerston North, New Zealand. ${ }^{2}$ PFR, Private Bag Private Bag 92169, Auckland 1142 New Zealand. ${ }^{3}$ PFR, Private Bag 4704 Christchurch, New Zealand.

Received: 28 February 2013 Accepted: 7 July 2013

Published: 13 July 2013

\section{References}

1. Santos-Rosa M, Poutaraud A, Merdinoglu D, Mestre P: Development of a transient expression system in grapevine via agro-infiltration. Plant Cell Rep 2008, 27(6):1053-1063.

2. Kapila J, DeRycke R, VanMontagu M, Angenon G: An Agrobacteriummediated transient gene expression system for intact leaves. Plant $\mathrm{SCi}$ 1997, 122(1):101-108.

3. Voinnet $O$, Rivas $S$, Mestre $P$, Baulcombe D: An enhanced transient expression system in plants based on suppression of gene silencing by the p19 protein of tomato bushy stunt virus. Plant J 2003, 33(5):949-956

4. Ratcliff F, Martin-Hernandez AM, Baulcombe DC: Tobacco rattle virus as a vector for analysis of gene function by silencing. Plant J 2001, 25(2):237-245.

5. Lu R, Martin-Hernandez AM, Peart JR, Malcuit I, Baulcombe DC: Virus-induced gene silencing in plants. Methods 2003, 30(4):296-303.

6. Chapman S, Kavanagh T, Baulcombe D: Potato virus-X as a vector for gene-expression in plants. Plant J 1992, 2(4):549-557.

7. Tamai A, Dohi K, Mori M, Meshi T, Ishikawa M: Inducible viral inoculation system with cultured plant cells facilitates a biochemical approach for virus-induced RNA silencing. Arch Virol 2010, 155(3):297-303.

8. Robertson D: VIGS vectors for gene silencing: Many targets, many tools. Annu Rev Plant Biol 2004, 55:495-519. 
9. Pacak A, Geisler K, Jorgensen B, Barciszewska-Pacak M, Nilsson L, Nielsen TH, Johansen E, Gronlund M, Jakobsen I, Albrechtsen M: Investigations of barley stripe mosaic virus as a gene silencing vector in barley roots and in Brachypodium distachyon and oat. Plant Methods 2010, 6:26.

10. Otulak K, Garbaczewska G: Cell-to-cell movement of three genera (+) ss RNA plant viruses. Acta Physiologiae Plantarum 2011, 33(2):249-260.

11. Lai H, He J, Engle M, Diamond MS, Chen Q: Robust production of virus-like particles and monoclonal antibodies with geminiviral replicon vectors in lettuce. Plant Biotechnol J 2012, 10(1):95-104.

12. Lindbo JA: High-efficiency protein expression in plants from agroinfection-compatible Tobacco mosaic virus expression vectors. BMC Biotechnol 2007, 7:52.

13. Sainsbury F, Canizares MC, Lomonossoff GP: Cowpea mosaic virus: the plant virus-based biotechnology workhorse. Annual Review of Phytopathology 2010 48:437-455.

14. Gleba Y, Marillonnet S, Klimyuk V: Engineering viral expression vectors for plants: the 'full virus' and the 'deconstructed virus' strategies. Curr Opin Plant Biol 2004, 7(2):182-188.

15. Marconi G, Albertini E, Barone P, De Marchis F, Lico C, Marusic C, Rutili D, Veronesi F, Porceddu A: In planta production of two peptides of the classical swine fever virus (CSFV) E2 glycoprotein fused to the coat protein of potato virus X. BMC Biotechnol 2006, 6 .

16. Sempere RN, Gomez P, Truniger V, Aranda MA: Development of expression vectors based on pepino mosaic virus. Plant Methods 2011, 7:6.

17. Manske U, Schiemann J: Development and assessment of a potato virus X-based expression system with improved biosafety. Environ Biosafety Res 2005, 4(1):45-57.

18. Hunter DA, Fletcher JD, Davies KM, Zhang HB: Colour break in reverse bicolour daffodils is associated with the presence of Narcissus mosaic virus. Virol J 2011, 8:412.

19. Leckie BM, Stewart CN Jr: Agroinfiltration as a technique for rapid assays for evaluating candidate insect resistance transgenes in plants. Plant Cell Rep 2011, 30(3):325-334.

20. Hayward A, Padmanabhan M, Dinesh-Kumar SP: Virus-induced gene silencing in Nicotiana benthamiana and other plant species. Methods in molecular biology (Clifton, NJ) 2011, 678:55-63.

21. Hellens RP, Allan AC, Friel EN, Bolitho K, Grafton K, Templeton MD, Karunairetnam S, Gleave AP, Laing WA: Transient expression vectors for functional genomics, quantification of promoter activity and RNA silencing in plants. Plant Methods 2005, 1:13.

22. Goodin MM, Zaitlin D, Naidu RA, Lommel SA: Nicotiana benthamiana: Its history and future as a model for plant-pathogen interactions. Mol Plant Microbe Interact 2008, 21(8):1015-1026.

23. Davies KM, Zhang HB, Schwinn KE: Recent advances in the molecular biology and metabolic engineering of flavonoid biosynthesis in ornamental plants. Recent Advances in Polyphenol Research, Vol 1 2008, 1:139-166.

24. Grotewold E: The genetics and biochemistry of floral pigments. Annu Rev Plant Biol 2006, 57:761-780.

25. Grotewold E, Davies K: Trafficking and sequestration of anthocyanins. Nat Prod Commun 2008, 3(8):1251-1258.

26. Quideau S, Deffieux D, Douat-Casassus C, Pouysegu L: Plant Polyphenols: Chemical properties, biological activities, and synthesis. Angew Chem Int Ed 2011, 50(3):586-621

27. Martin C, Butelli E, Petroni K, Tonelli C: How can research on plants contribute to promoting human health? Plant Cell 2011, 23(5):1685-1699.

28. Hichri I, Barrieu F, Bogs J, Kappel C, Delrot S, Lauvergeat V: Recent advances in the transcriptional regulation of the flavonoid biosynthetic pathway. J Exp Bot 2011, 62(8):2465-2483.

29. Shi BJ, Ding SW, Symons RH: Plasmid vector for cloning infectious CDNAs from plant RNA viruses: High infectivity of cDNA clones of tomato aspermy cucumovirus. J Gen Virol 1997, 78:1181-1185.

30. Haseloff J, Siemering KR, Prasher DC, Hodge S: Removal of a cryptic intron and subcellular localization of green fluorescent protein are required to mark transgenic Arabidopsis plants brightly. Proc Natl Acad Sci USA 1997, 94(6):2122-2127.

31. Finer JJ, Vain P, Jones MW, McMullen MD: Development of the particle inflow gun for DNA delivery to plant-cells. Plant Cell Rep 1992, 11(7):323-328.

32. Shang YJ, Schwinn KE, Bennett MJ, Hunter DA, Waugh TL, Pathirana NN, Brummell DA, Jameson PE, Davies KM: Methods for transient assay of gene function in floral tissues. Plant Methods 2007, 3.
33. Borevitz JO, Xia YJ, Blount J, Dixon RA, Lamb C: Activation tagging identifies a conserved MYB regulator of phenylpropanoid biosynthesis. Plant Cell 2000, 12(12):2383-2393.

34. Agalou A, Roussis A, Spaink HP: The Arabidopsis selenium-binding protein confers tolerance to toxic levels of selenium. Funct Plant Biol 2005, 32(10):881-890.

35. Scholthof $H B$, Scholthof KBG, Jackson $A O$ : Plant virus gene vectors for transient expression of foreign proteins in plants. Annu Rev Phytopathol 1996, 34:299-323.

36. Regnard GL, Halley-Stott RP, Tanzer FL, Hitzeroth II, Rybicki EP: High level protein expression in plants through the use of a novel autonomously replicating geminivirus shuttle vector. Plant Biotechnol J 2010, 8(1):38-46.

37. Sainsbury F, Thuenemann EC, Lomonossoff GP: pEAQ: versatile expression vectors for easy and quick transient expression of heterologous proteins in plants. Plant Biotechnol J 2009, 7(7):682-693.

38. Gleba Y, Klimyuk V, Marillonnet S: Viral vectors for the expression of proteins in plants. Curr Opin Biotechnol 2007, 18(2):134-141.

39. Daskalova SM, Radder JE, Cichacz ZA, Olsen SH, Tsaprailis G, Mason H, Lopez LC: Engineering of $N$. benthamiana L. plants for production of $\mathrm{N}$-acetylgalactosamine-glycosylated proteins - towards development of a plant-based platform for production of protein therapeutics with mucin type O-glycosylation. BMC Biotechnol 2010, 10:62.

40. Fukuzawa N, Ishihara T, Itchoda N, Tabayashi N, Kataoka C, Masuta C, Matsumura T: Risk-managed production of bioactive recombinant proteins using a novel plant virus vector with a helper plant to complement viral systemic movement. Plant Biotechnol J 2011, 9(1):38-49.

41. Pogue GP, Vojdani F, Palmer KE, Hiatt E, Hume S, Phelps J, Long L, Bohorova $N$, Kim D, Pauly $M$, et al: Production of pharmaceutical-grade recombinant aprotinin and a monoclonal antibody product using plant-based transient expression systems. Plant Biotechnol J 2010, 8(5):638-654.

42. Zhang YL, Li J, Pu H, Jin J, Zhang XF, Chen MK, Wang B, Han CG, Yu JL, Li DW: Development of Tobacco necrosis virus $A$ as a vector for efficient and stable expression of FMDV VP1 peptides. Plant Biotechnol J 2010, 8(4):506-523.

43. Komarova TV, Baschieri S, Donini M, Marusic C, Benvenuto E, Dorokhov YL: Transient expression systems for plant-derived biopharmaceuticals. Expert Rev Vaccines 2010, 9(8):859-876.

44. Karasev AV, Poplawsky AR, Blades BS, Dibble M, Ding H, Dolja W, Eigenbrode SD: Nicotiana benthamiana as a model plant to study aphid transmission of plant viruses. Phytopathology 2009, 99(6):S61-S61.

45. Todd AT, Liu EW, Polvi SL, Pammett RT, Page JE: A functional genomics screen identifies diverse transcription factors that regulate alkaloid biosynthesis in Nicotiana benthamiana. Plant J 2010, 62(4):589-600.

46. Huang FC, Studart-Witkowski C, Schwab W: Overexpression of hydroperoxide lyase gene in Nicotiana benthamiana using a viral vector system. Plant Biotechnol J 2010, 8(7):783-795.

47. van Herpen T, Cankar K, Nogueira M, Bosch D, Bouwmeester HJ, Beekwilder J: Nicotiana benthamiana as a production platform for artemisinin precursors. PLoS One 2010, 5(12):e14222

48. Mann DGJ, LaFayette PR, Abercrombie LL, King ZR, Mazarei M, Halter MC Poovaiah CR, Baxter H, Shen H, Dixon RA, et al: Gateway-compatible vectors for high-throughput gene functional analysis in switchgrass (Panicum virgatum L.) and other monocot species. Plant Biotechnol J 2012, 10(2):226-236.

49. Skalamera D, Ranall MV, Wilson BM, Leo P, Purdon AS, Hyde C Nourbakhsh E, Grimmond SM, Barry SC, Gabrielli B, et al: A high-throughput platform for lentiviral overexpression screening of the human ORFeome. PLoS One 2011, 6(5).

50. Sasagawa T, Matsui M, Kobayashi $Y$, Otagiri M, Moriya S, Sakamoto Y, Ito Y, Lee CC, Kitamoto K, Arioka M: High-throughput recombinant gene expression systems in Pichia pastoris using newly developed plasmid vectors. Plasmid 2011, 65(1):65-69.

51. Lacorte C, Ribeiro SG, Lohuis D, Goldbach R, Prins M: Potato virus X and Tobacco mosaic virus-based vectors compatible with the Gateway (TM) cloning system. J Virol Methods 2010, 164(1-2):7-13.

52. Borges JP, Culerrier R, Aldon D, Barre A, Benoist H, Saurel O, Milon A, Didier A, Rouge P: GATEWAY (TM) technology and E. coli recombinant system produce a properly folded and functional recombinant allergen of the lipid transfer protein of apple (Mal d 3). Protein Expr Purif 2010, 70(2):277-282.

53. Triguero A, Cabrera G, Rodriguez M, Soto J, Zamora Y, Perez M, Wormald MR, Cremata JA: Differential N-glycosylation of a monoclonal 
antibody expressed in tobacco leaves with and without endoplasmic reticulum retention signal apparently induces similar in vivo stability in mice. Plant Biotechnol J 2011, 9(9):1120-1130.

54. Oparka KJ, Roberts AG, Prior DAM, Chapman S, Baulcombe D, SantaCruz S: Imaging the green fluorescent protein in plants - Viruses carry the torch. Protoplasma 1995, 189(3-4):133-141.

55. Baulcombe DC, Chapman S, Cruz SS: Jellyfish green fluorescent protein as a reporter for virus-infections. Plant J 1995, 7(6):1045-1053.

56. Pfalz M, Mikkelsen MD, Bednarek P, Olsen CE, Halkier BA, Kroymann J: Metabolic Engineering in Nicotiana benthamiana reveals key enzyme functions in Arabidopsis indole glucosinolate modification. Plant Cell 2011, 23(2):716-729.

57. Moldrup ME, Geu-Flores F, Olsen CE, Halkier BA: Modulation of sulfur metabolism enables efficient glucosinolate engineering. BMC Biotechnol 2011, 11(12):31.

58. Albert NW, Arathoon S, Collette VE, Schwinn KE, Jameson PE, Lewis DH, Zhang H, Davies KM: Activation of anthocyanin synthesis in Cymbidium orchids: variability between known regulators. Plant Cell Tiss Org Cult 2010, 100(3):355-360.

59. Albert NW, Lewis DH, Zhang H, Schwinn KE, Jameson PE, Davies KM: Members of an R2R3-MYB transcription factor family in Petunia are developmentally and environmentally regulated to control complex floral and vegetative pigmentation patterning. Plant $J 2011$, 65(5):771-784

60. Kui LW, Bolitho K, Grafton K, Kortstee A, Karunairetnam S, McGhie TK, Espley RV, Hellens RP, Allan AC: An R2R3 MYB transcription factor associated with regulation of the anthocyanin biosynthetic pathway in Rosaceae. BMC Plant Biol 2010, 10.

61. Gutha LR, Casassa LF, Harbertson JF, Naidu RA: Modulation of flavonoid biosynthetic pathway genes and anthocyanins due to virus infection in grapevine (Vitis vinifera L.) leaves. BMC Plant Biol 2010, 10:187.

62. Butelli E, Titta L, Giorgio M, Mock H-P, Matros A, Peterek S, Schijlen EGWM, Hall RD, Bovy AG, Luo J, et al: Enrichment of tomato fruit with health-promoting anthocyanins by expression of select transcription factors. Nat Biotechnol 2008, 26(11):1301-1308.

63. Naithani R, Huma LC, Holland LE, Shukla D, McCormick DL, Mehta RG, Moriarty RM: Antiviral activity of phytochemicals: A comprehensive review. Mini Rev Med Chem 2008, 8(11):1106-1133.

64. Bedoya LC, Martinez F, Orzaez D, Daros J-A: Visual tracking of plant virus infection and movement using a reporter MYB transcription factor that activates anthocyanin biosynthesis. Plant Physiol 2012, 158(3):1130-1138.

doi:10.1186/1746-4811-9-28

Cite this article as: Zhang et al.: A Narcissus mosaic viral vector system for protein expression and flavonoid production. Plant Methods 2013 9:28.

\section{Submit your next manuscript to BioMed Central and take full advantage of:}

- Convenient online submission

- Thorough peer review

- No space constraints or color figure charges

- Immediate publication on acceptance

- Inclusion in PubMed, CAS, Scopus and Google Scholar

- Research which is freely available for redistribution 